\title{
Necropolitics and the Violence of Indigenous Incarceration
}

\author{
Kirstie Broadfield ${ }^{1}$, Glenn Dawes ${ }^{2} \&$ Mark David Chong $^{3}$
}

\begin{abstract}
Since the Royal Commission into Aboriginal Deaths in Custody, over thirty years ago, there have been over 400 Indigenous deaths in custody, with $28 \%$ of the Australian prison population identifying as Indigenous. Indigenous overrepresentation in the criminal justice system continues to be an unresolved issue despite varying attempts to reduce the high incidence of incarceration experienced by Indigenous Australians. This paper proposes a fresh approach to analysing the violence of Indigenous incarceration using the theory of necropolitics. The paper represents a critical discussion of an ongoing research project that demonstrates how an analytical framework based on necropolitics has the potential to elevate the often silenced voices of vulnerable populations, such as Indigenous Australians, within the criminal justice system. This is because the study will present a multi-level analysis of the overt and covert forms of violence perpetrated against Indigenous Australians within the criminal justice system and unlock the potential of exposing the extent to which unequal relations of power contribute to these forms of violence. The significance of this research therefore lies in its capacity to provide policymakers with deeper insights into how such forms of violence impact upon and further disempower Indigenous Australians in the Australian criminal justice system.
\end{abstract}

Keywords: Indigenous Australian, violence, incarceration, necropolitics, necropower, criminal justice

\footnotetext{
${ }^{1}$ James Cook University, Australia

2 James Cook University, Australia

3 James Cook University, Australia
} 


\section{Introduction}

Tackling overt forms of violence is the central focus of many media and government campaigns regarding the reduction of violent crime. What happens though, when overt and covert forms of violence not only target vulnerable populations but are systemic, hidden or embedded within policies and practices of the criminal justice system itself? (see Baldry, Carlton, \& Cunneen, 2015; Blagg \& Anthony, 2019; Howlett, 2009; Morseu-Diop, 2017). It has been more than 30 years since the convening of the Royal Commission into Aboriginal Deaths in Custody (1987-1991), but since then there have been over 400 Indigenous deaths in custody, with $28 \%$ of the Australian prison population identifying as Indigenous (Australian Bureau of Statistics, 2018a; Wahlquist, 2016). It is important to put these figures into context because Indigenous Australians only constitute approximately 3\% of the total Australian population (Australian Bureau of Statistics, 2018b).

In 2009, the Social Justice Commissioner stressed a need for Australia to think 'outside the box' on Indigenous Australian offending instead of 'revalorising' imprisonment as a frontline criminal justice strategy (Aboriginal \& Torres Strait Islander Social Justice Commissioner, 2009). Indigenous overrepresentation in the criminal justice system continues to be an unresolved issue despite varying attempts to reduce the high incidence of incarceration experienced by Indigenous Australians. These attempts include legislation that targets habitual recidivists, such as the Habitual Criminals Act 1957 in NSW, which "provides for the pronouncement, detention and control of habitual criminals" (Drabsch, 2006, p. 20); the diversion of first-time or non-serious offenders through cautioning or conferencing (Allard et al., 2010); rehabilitation programmes in correctional centres to reduce re-entry into the justice system (Drabsch, 2006); magistrate ordered redirection into community-based substance abuse rehabilitation programmes (Drabsch, 2006); intensive, supervised probation or parole (Drabsch, 2006); and vocational education programmes (Drabsch, 2006).

The research project detailed in this paper, therefore, attempts to think about Indigenous incarceration laterally and 'outside the box' through the use of necropolitics, not only as a theoretical framework for exposing those forms of violence experienced by Indigenous Australians in the criminal justice system but also as a potential emancipatory vehicle for elevating the previously silenced voices of Indigenous Australians in 
criminal justice research. The paper begins with a brief historical context to Indigenous incarceration and the criminalisation of Indigenous Australians in contemporary Australia before it outlines the aims, objectives, methodology, perceived outcomes and, of course, the theoretical framework of the ongoing research project.

\section{A History of Indigenous Incarceration}

British sovereignty, according to Moreton-Robinson (2015) is based on "possessive logics of patriarchal white sovereignty" (p. xi) due to the fact that it is "a regime of power that derives from the illegal act of possession" (p. 34), whereby terra nullius was illegitimately assigned in order to take possession of Australia in the name of the king. Moreton-Robinson (2015), therefore, reinforces Wolfe's (1999) claims that settler-colonial sovereignty was embedded with the 'logic of elimination' when he states that "[t]he performative act of possession enabled by patriarchal white sovereignty is constituted by violence, and transgression, voyeurism, pleasure, and pride" (p. 36). Thus, from the very beginning of settler-colonial control, Indigenous Australia was in a 'state of siege' - a condition that "allows a modality of killing that does not distinguish between the external and internal enemy" (Mbembe, 2003, p. 30). Resistance by Indigenous Australians to the continuing dispossession by settler-colonials saw them soon become the enemy within, as demonstrated by the open warfare conducted by the settler-colonials against their 'internal enemies' in the early contact period of Australia (Bottoms \& Evans, 2013; Cunneen \& Tauri, 2017; Elder, 2003; Reynolds, 2001, 2006, 2012, 2013). During this state of siege, however, it became apparent that Indigenous Australians were not going to be as easy to overcome as the settler-colonials had initially believed because, as Dunbar-Ortiz states, "[p]eople do not hand over their land, resources, children and futures without a fight" (as cited in Cunneen, 2007, p. 46).

Thus, the settler-colonials replaced their strategy of open warfare against Indigenous Australians and began institutionalising the violence against the 'internal enemy' by "impos[ing] a colonial system of criminal justice" on them (Dunbar-Ortiz as cited in Cunneen, 2007, p. 46). The criminalisation of Indigenous Australians allowed a legalised level of social control of Indigenous Australians through "surveillance, intervention and control outside of, and in contradistinction to the 'universal' rights of liberal subjects" (Baldry \& Cunneen, 2012, p. 5). To achieve hegemonic 
control, these settler-colonials have since the eighteenth century attempted to "eliminate, restructure and reconstitute" the Indigenous Australian identity (Blagg, 2008, p. 3), with the process of criminalisation being used as yet another tool to accomplish that objective. In the eighteenth and early nineteenth centuries, crimes perceived to have been undertaken by Indigenous Australians were met with harsh penalties (Anthony, 2013). Into the late nineteenth and early twentieth centuries, strategies to control the 'enemy within' turned towards protection and assimilation (Australian Law Reform Commission, 2018). 'Protection' laws were designed to restrict contact (especially sexual relationships) between 'full-blood' Indigenous Australians and the settler-colonials, which was done by isolating the Indigenous Australians on reserves in order to 'protect' them, while the assimilation laws legalised the removal of 'half-caste' children from their Indigenous families where they were institutionalised and educated in 'European' norms (Australian Law Reform Commission, 2018). These laws further criminalised Indigenous Australians by imposing criminal penalties for breaching them (Anthony, 2013; Cunneen, 2007).

It is arguable that even during the late twentieth and early twentyfirst centuries, there have been ongoing attempts to 'civilise' Indigenous Australians as part of prior assimilation policies, and where resistance to these attempts arose, harsh penalties were imposed (Anthony, 2013). Such continuing criminalisation and punishment of Indigenous Australians may well be considered by certain quarters to be vital to ensuring the ongoing success of settler colonialism. This argument that the settler-colonial justice system has been used as a mechanism of controlling Indigenous Australians is cogently summed up by Anthony (2013), who states:

Dispensing the criminal law was a vehicle for punishing and containing Indigenous people through a seemingly neutral mechanism. Violence dressed up as 'punishment' created a logic that it was the normal response to Indigenous people on the frontier and beyond. Punishment for crimes meant that the repression and restraint of Indigenous people was not an abuse of power, but a justification for the use of power (p. xii). 


\section{Indigenous criminalisation in contemporary Australia}

When examining the nature and quality of police interaction with members of the community today, one must especially consider the size of the Indigenous Australian population. For all states studied ${ }^{1}$, except for the Northern Territory, non-Indigenous Australians have more interaction in total numbers with the police than Indigenous Australians. However, when police interactions are viewed from the perspective of Indigenous and nonIndigenous population proportions, a different pattern emerges with all states showing a higher police interaction rate with Indigenous Australians in comparison to non-Indigenous Australians (Figure 1).

Figure 1. Average Police Interactions by State, 2008 - 2017.

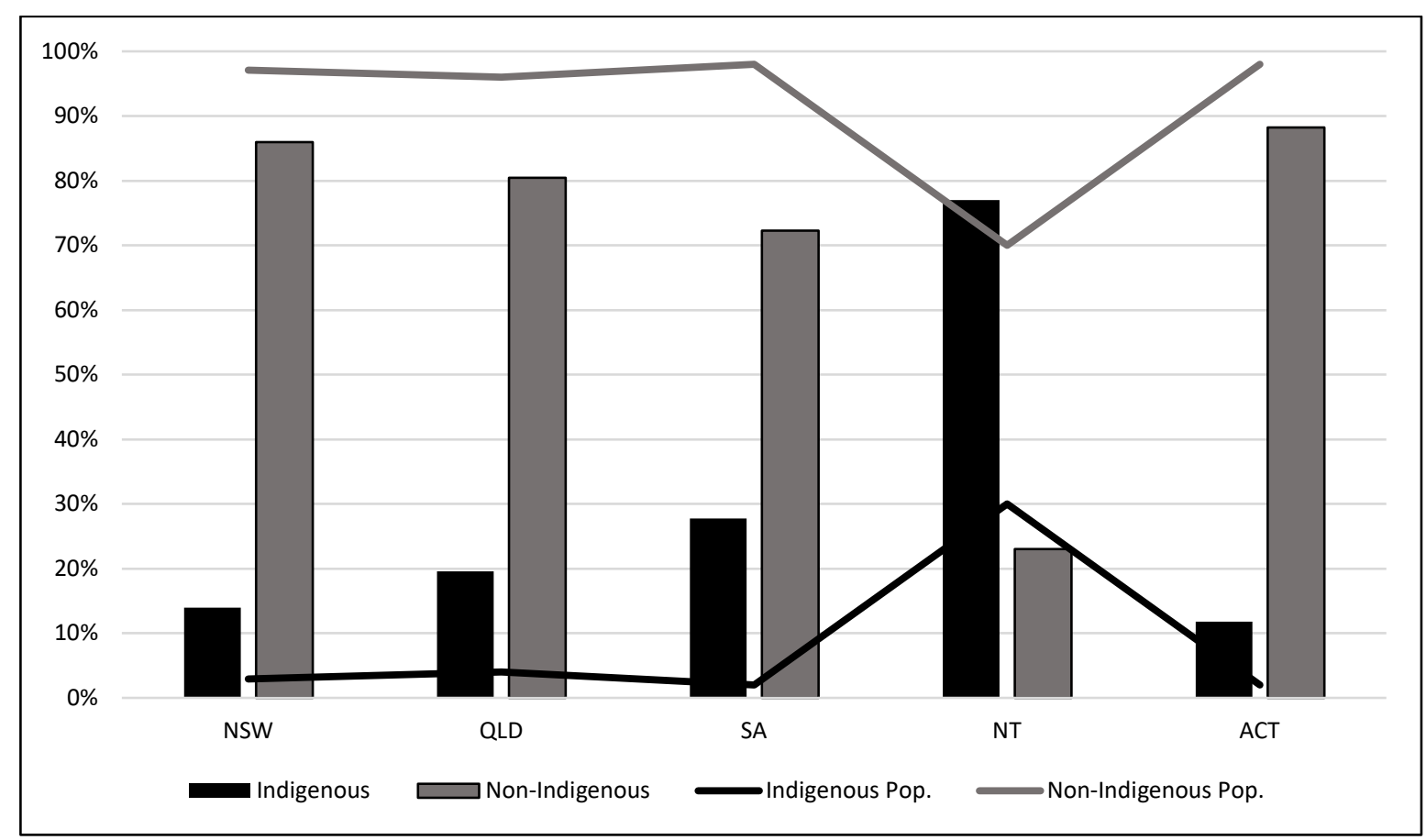

Furthermore, in the June Quarter of 2018, 28\% of the total Australian prison population identified as Indigenous, with three states contributing almost three-quarters of those prisoners - these three states being New South Wales (29\%), Queensland (23\%) and Western Australia $(23 \%)$. On top of these figures, the national average daily imprisonment rate for Indigenous Australian people was 2,505 persons per 100,000 Indigenous Australian adults. The highest imprisonment rates per 100,000 Indigenous Australian adults were recorded in Western Australia at 4,252; 
Northern Territory at 2,984; and South Australia with 2,533 (Australian Bureau of Statistics, 2018a).

Figure 2 illustrates average prison populations (2008-2017) by state alongside Indigenous and non-Indigenous population sizes for those states. Again, all states demonstrate significant overrepresentation of Indigenous Australians in their prisons.

Figure 2. Average Australian Prisoners by State, 2008 - 2017.

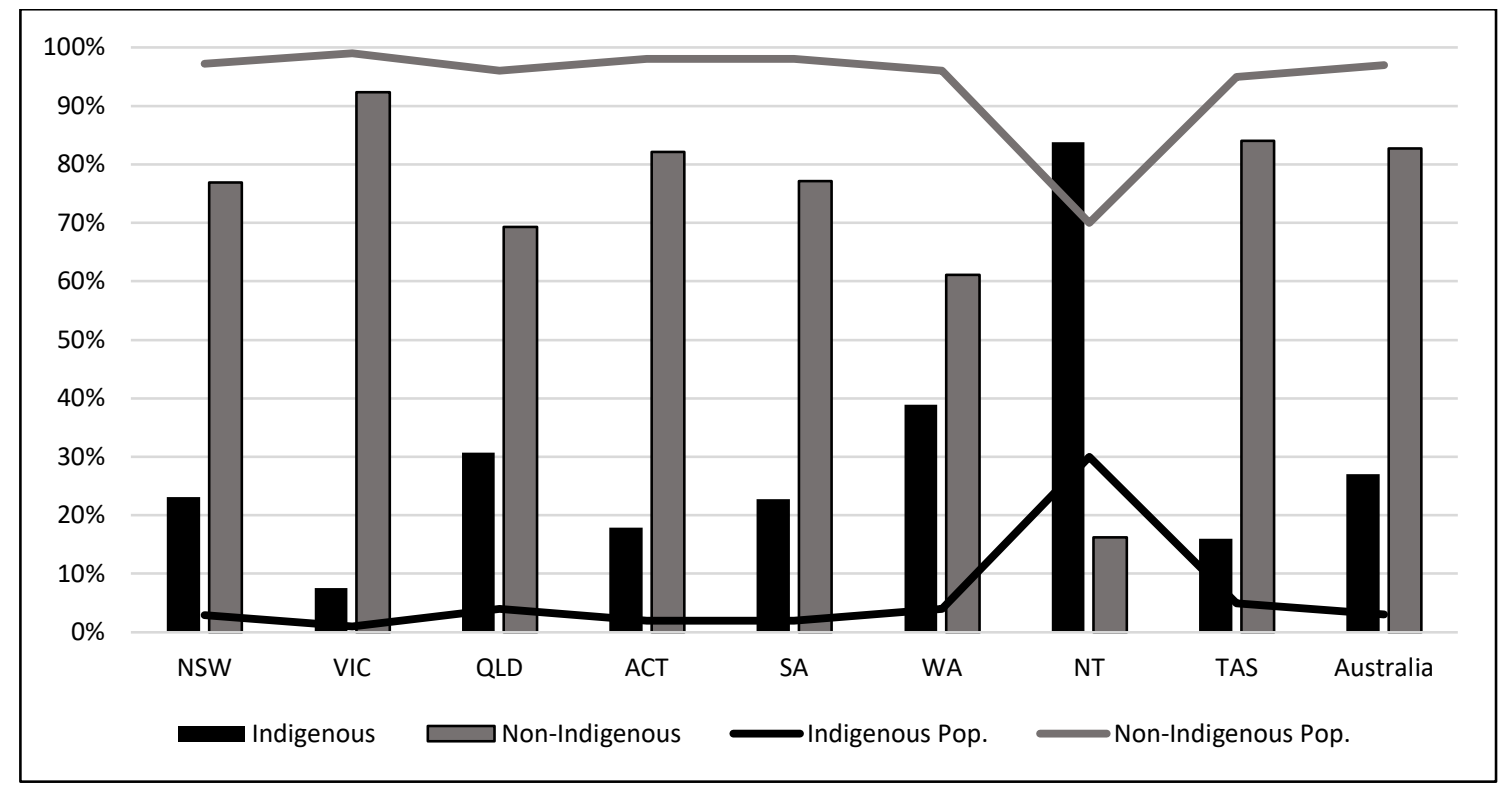

These figures, even when taken at face value, should be cause for alarm, particularly when one considers the underlying intergenerational impact of colonisation, as well as the 1,358 custodial deaths of Indigenous Australians between 1980 and 2017 (Baker \& Cussen, 2015; Cunrow, Larsen, 2007, 2008; Gannoni \& Bricknell, 2017, 2019; Lyneham \& Chan, 2013; Lyneham, Larsen, \& Beacroft, 2008; Ticehurst, Napier, \& Bricknell, 2018) - a highly disturbing trend emerges, one that begs closer scrutiny.

The next section will, therefore, detail the proposed research project, the positionality of the researcher (the first author), and the potential for the theoretical framework of necropolitics to uncover greater insights into the issue of Indigenous overrepresentation in the criminal justice system.

\section{A different approach to Indigenous incarceration}

Kenneth Parsons (2007) wrote that, 
"the relations between organized patterns of activity (that is structures) and the level of agency of subordinate, oppressed or marginalised groups is under-theorized in terms of struggles over unjust relations of power and relations of violence" (p. 173).

Twelve years later, in 2020, it is arguable that those relations of power and relations of violence, vis-à-vis Indigenous Australians and the criminal justice system, are still vastly under-theorised. Hence, this research project will focus on the relations of power and the resulting violence experienced by Indigenous Australian people in the criminal justice system, with Queensland as its focal point. To that end, this research study attempts to unveil the extent to which unequal relations of power contribute to forms of violence experienced by Indigenous Australian people in the criminal justice system.

Over the last quarter of a century, most research into crime and criminal justice has been undertaken through methods that have privileged state-centred perspectives and, arguably, this has often perpetuated the silencing of the Indigenous perspective and voice. The omission of Indigenous voices in research on Indigenous incarceration, according to Edney, as cited in Hagan (2017):

...continues to this day in terms of the research conducted on Indigenous imprisonment. Indigenous prisoners in this penal dialogue are viewed as objects, not subjects, and their understanding of imprisonment are neglected (p. 5).

It should be noted that a vast majority of criminological research is performed on behalf of the powerful, those actors, interests and institutions that create, maintain and control the "definitions, labels and boundaries of crime and markers of criminality" (Lumsden \& Winter, 2014, p. 1). Criminology, of all disciplines in the social sciences, has "the most dangerous relationship to power" (Hudson, as cited in Lumsden \& Winter, 2014 , p. 1). This is due to its perpetuation of criminal stereotypes - for example, Cesare Lombroso's atavistic ‘born' criminal - which affects the persons to whom these labels are applied and robs them of the rights and liberties to which they are due as human beings (Lumsden \& Winter, 2014).

Lynch (as cited in Cunneen \& Tauri, 2017, p. 25), posits that "the history of criminology has been the story of humanly created methods of 
oppression told from the oppressor perspective". Furthermore, Lynch postulates that criminology was designed to control the "free and unfettered creativity of the criminal classes" (Cunneen \& Tauri, 2017, p. 26). This argument is supported by Biko Agozino (2010) who states that criminology is a "control-freak discipline", in that it is a "technology designed for the control of others" (p. ii); in other words - a "science of oppression" (Lynch as cited in Cunneen \& Tauri, 2017, p. 26).

These somewhat pessimistic views stem from a mainstream form of criminology that emerged from positivist approaches to medicine, law, anthropology, and evolution that understood crime as primarily being a "breach of state criminal law" (Cunneen, 2011a, p. 260), and where statistics on offences were produced by state agencies to reflect that particularly narrow conception of crime (Cunneen, 2011a). However, by extending criminology past the positivist approach, one can start to conceptualise the nature and extent of crime committed by the state and not just against the state (Cunneen, 2011a). This extension of criminology has allowed critical criminology to develop, whereby researchers can start to interrogate the possibility of how the criminal justice system can be used to colonise, marginalise and stigmatise Indigenous Australian people (Cunneen, 2011a; Cunneen \& Tauri, 2017).

Critical criminology, pioneered by Jock Young, challenges the mainstream positivist and normative criminologies that dominate criminological research, and advocates for a 'criminological imagination' (Lumsden \& Winter, 2014) to deepen our understanding of the true realities of life. Criminologists such as Janet Chan (2000), Chris Cunneen (2011b), and Thalia Anthony (2009) support Young's call for research that "uses an optic which envisages the wide spectrum of human experience: the crime and law-abiding citizen, the deviant and the supposedly normal the whole round of human life" (Lumsden \& Winter, 2014, p. 1).

For this 'criminological imagination' to be realised, research must be both critical and reflexive and sit within an emancipatory-transformative paradigm, which is post-positivist by nature (Lumsden \& Winter, 2014; McCabe \& Holmes, 2009; O'Leary, 2004; Oliver, 1992). Hence, the proposed research adopts a new approach to criminological research with Indigenous Australian people by using an emancipatory-transformative paradigm together with post-positivist and phenomenological elements. To that end, a vital aim of this study is to include these previously silenced voices of Indigenous Australians by providing them with a platform to 
express their perceptions and understandings of their lived experiences in the criminal justice system.

\section{Positionality of a non-Indigenous researcher}

Research, by its very nature, is a political beast, and no matter which paradigmatic stance a researcher takes, they must be aware of this fact and manage the position of power they are in as a researcher (O'Leary, 2004). Furthermore, it is important for researchers to fully comprehend the influence that power can have in the process of their research (O'Leary, 2004). The age-old adage 'with great power comes great responsibility' holds especially true with respect to research; particularly research that is being conducted with vulnerable populations. Power was defined by Foucault (1983) as:

A total structure of actions [...] it incites, it seduces, it makes easier or more difficult; in the extreme it constrains or forbids absolutely; it is nevertheless always a way of acting upon an acting subject or acting subjects by virtue of their acting or being capable of action. A set of actions upon other actions (p. 220)

Researchers must be aware of the power dynamics involved in their endeavours and how they can influence the outcome of the research by continually looking to redress any imbalances of power that arise where the voices of the participants may be silenced (Rowe W., 2014).

Positionality, on the other hand, is about the researcher being aware of their "political emotions" (Hage, as cited in Petray, 2012, p. 556) in relation to the context, both socially and politically, of the project (Rowe W., 2014). Political emotions, according to Hage, are "those emotions related to our sense of power over ourselves and our environments as we pursue those goals, ideals and activities that give our life a meaning" (as cited in Petray, 2012, p. 556). Thus, political emotions will differ from person to person given that social realities and identities also vary from person to person (Petray, 2012). For those researchers working with vulnerable people, it is important to recognise that many "outwardly struggle against some kind of oppression and injustice" (Petray, 2012, p. 556).

Petray (2012) suggests that to become part of this community of research participants "requires us to empathise with the injustice, which often entails identifying the 'oppressor' and developing negative emotions 
towards them" (p. 556). However, Petray also warns against the influence that this positionality can have on the research and recommends that the researcher examines where their political emotions are emanating from so that they can "remain an engaged researcher, embedded in the cause and an advocate for [their] participants, while not experiencing things in the same way [as the participants]" (p. 561). Ultimately, the positionality of the researcher has the potential to impact the outcomes of the research, i.e., whose 'voices' will be effectively heard in the final product (Rowe W., 2014).

To this end, the researcher (i.e., the first author) acknowledges that her reality, and therefore her positionality, not only as a researcher but also as a White, British-born, middle-class, educated woman may well be in distinct opposition to the reality of the participants. Throughout this research, from the initial proposal; to the ethics process; to the formulation of the semi-structured interview questions; and the analysis of the data this positionality has been held firmly in mind.

The drive behind this research project mirrors wholeheartedly that of Simone Rowe (2014) who states:

...I am an outsider to the Indigenous colonised experience, an allied 'other' driven by a desire to expose and transform the myriad injustices that continue to oppress, objectify, dehumanise and criminalise Indigenous people...This project gave me an opportunity to reinvigorate, and at least partially realise, that aim" (p. 5).

Therefore, it is imperative that this research project be conducted with, and not on, Indigenous Australian people. Furthermore, the first author's stance throughout this research has been inherently political, as encouraged by Cunneen and Tauri (2017), because it:

- Privileges the perspectives, experiences and issues of Indigenous [Australian] peoples;

- Critically analyses the activities of the powerful, such as policy makers [...] and criminal justice institutions; and

- Offers [recommendations] to [criminal justice institutions] and policy praxis that empowers Indigenous [Australian] peoples in their attempts at self-determination. (p. 35). 


\section{Necropolitics as a theoretical framework}

The theory of necropolitics emerged from Africa through the works of Achilles Mbembe and originates from the violence that was inflicted within an African political context. The theory of necropolitics is influenced by Michel Foucault and Giorgio Agamben. Foucault considered biopower a central element of what he termed 'biopolitics', which he espoused was "to optimise and develop life within operations of modern governance against the traditional right of sovereign power to take the life of subjects" (Brigg, 2007, p. 406). Mbembe (2003) transmogrifies Foucault's concept of biopolitics into necropolitics by proposing that sovereignty confers the "capacity to define who matters and who does not, who is disposable and who is not" (p. 27), and, according to Lytle (2017), to "assert who belongs" (p. 27). Mbembe (2003) applies this to late-modern colonisation in the Palestinian context as "a concatenation of multiple powers: disciplinary, biopolitical and necropolitical" (as cited in Frey \& Ruch, 2006, p. 7). Agamben's concept of 'state of exception' informed Mbembe's view of how surplus populations are managed in the colonies. Agamben's influence is clear when Mbembe refers to the plantations of Africa, stating that they "manifest the emblematic and paradoxical figure of the state of exception" (Mbembe, 2003, p. 21) where the slave is "[t]reated as if he or she no longer existed except as a mere tool" (p. 22).

For Mbembe, Africa is in a state of war where dehumanisation and configurations of power are deeply entrenched; a state he refers to as 'necropolitics' (Mbembe, 2003). He defines necropolitics as "the material destruction of human bodies and populations" (Mbembe, 2003, p. 14) through the exercising of necropower, which is a form of power that subjugates "life to the power of death" (Mbembe, 2003, p. 39). Necropower operates where the state not only has the right to kill but can also initiate the 'social death' of populations by classifying them as 'inferior' (Tedmanson, 2008). Necropower is at the heart of necropolitics, and as Soyinka-Airewele (2015) warns, such power "tends to mutate towards decay, abuse and violence" (p. 3). Certainly, one only has to "cite the names of the dead to recall the long history of deadly police racial profiling" (Smith, 2015, p. 385) to behold the mutation of necropower into violence in many post-colonial countries. In other words, the state has the power to decide who lives or who dies (physically, politically and/or socially); who is disposable and who is not; as well as who matters and who does not (Mbembe, 2003; Sclofsky, 2016; Soyinka-Airewele, 2015). 
These deaths occur in what Mbembe (2003) refers to as 'deathworlds' where specific populations "are subjected to the conditions of life conferring upon them the status of the living dead" (p. 17, emphasis in the original). Mbembe's concept of 'death-worlds' is based on the lives of slaves in African plantations where a slave is scarred by losses: "loss of a 'home', loss of rights over his or her body, and loss of political status" (as cited in Vadasaria, 2015, p. 119). This social and political 'death' creates a body that is 'dead' but is still in possession of a soul (Sithole, 2014); a body that exists in a "state of injury, in a phantomlike world of horrors and intense cruelty and profanity" (Mbembe, 2003, p. 21). Mbembe's three concepts of necropolitics, necropower, and death-worlds are founded on the state's objectification and dehumanisation of the African population through the suspension of life through physical, social and political deaths; necropolitics is, therefore, a politics of death.

The decision to use necropolitics as a theoretical framework for this research came from Rebecca Bromwich's (2017) article 'Theorizing the official record of inmate Ashley Smith: Necropolitics, exclusions, and multiple agencies', in which she states:

Necropolitics as a theorisation of this formulation of power is especially useful because it allows for understanding of certain subjects as occupying statuses that are neither living or dead, and it offers an accounting for the power of the state to impose death and death-like status on subjects. (p. 197)

Necropolitics is based on a logic of destruction either through genocide or by confining whole populations to conditions where they are faced with inescapable violence (Bargu, 2016), where they exist as the "unduly constrained slain-in-waiting" (Kwate \& Threadcraft, 2018, p. 539); living in constant fear of violent death, not unlike what many African Americans in the United States have expressed in ongoing Black Lives Matter protests (Hope, Keels \& Durkee, 2016).

This suggests that necropolitics requires sites of violence in which to operate, certainly, for Indigenous Australians, both prison and police cells have lamentably become sites of violence; sites for necropolitics to arise (Klippmark, 2016; Kwate \& Threadcraft, 2018). Mbembe himself states that necropolitics poses the question "what place are wounded and slain bodies [Indigenous Australian bodies in the context of this research] given in politics?". In other words, what attention is given to the forms of violence 
experienced by Indigenous Australians in the criminal justice system and the role that unequal relations of power play in this violence?

Although used in relatively niche areas of research, necropolitics as a framework for analysing violence has been used successfully in the analysis of state violence against minority groups, such as Indigenous peoples; the LGBTQI+ community; and asylum seekers, refugees and migrants (e.g., Bassichis \& Spade, 2014; Bromwich, 2017; Davies, Isakjee \& Dhesi, 2017; Haritaworn, 2010; Kwate \& Threadcraft, 2018; Razack, 2012, 2013; Round \& Kuznetsova, 2016). In fact, very promisingly, research concerning Indigenous peoples using a necropolitical framework has focussed strongly on so-called 'post-colonial' countries in Africa, as well as Canada, the United States, Brazil, and to a lesser extent Australia (e.g., Alves, 2014; Bromwich, 2017; Holcombe, 2016; Klippmark, 2016; Klippmark \& Crawley, 2017; Rana \& Rosas, 2006; Razack, 2012, 2013; Scheper-Hughes, 2006; Smith, 2015, 2016; Soyinka-Airewele, 2015; Tedmanson, 2008). In Australia, however, it is arguable that not enough research looks specifically at Indigenous offenders as victims, and the judicial system as being necropolitical in nature; although, five pieces of work in this regard stand out:

1. Deirdre Tedmanson's article 'Isle of exception: Sovereign power and Palm Island' (2008) focuses on the death in custody of $\mathrm{Mr}$ Doomadgee in 2004.

2. Pauline Klippmark's honours thesis, 'Justice for Ms Dhu: Disrupting the framing of state violence and Indigenous women's deaths in custody through commemoration in the public sphere' (2016), centres on the death in custody of Ms Dhu in 2014.

3. Karen Crawley, with Pauline Klippmark, wrote 'Justice for Ms Dhu: Accounting for Indigenous deaths in custody in Australia' (2017), which while still focusing on Ms Dhu's death in custody, addresses also the gendered, institutional and structural forms of racism in Australia.

4. Sarah Holcombe's work 'Human Rights, Colonial Criminality, and the Death of Kwementyaye Briscoe in Custody: A Central Australian Case Study' (2016), analyses the death of Mr Briscoe in 2012.

5. Finally, the Deathscapes project by Suvendrini Perera and Joseph Pugliese. Although it is not confined to Australia alone, the work by the Deathscapes team views Indigenous deaths in custody through a necropolitical lens as the ongoing assertion of settler-colonial sovereignty through state violence. 


\section{Methodology}

Before applying the theory of necropolitics to the empirical data, it first needs to be operationalised. Operationalising is the process of specifying the operations that will indicate the value of a variable for each case (Neuman \& Wiegand, 2000). The goal is to devise operations that measure the concepts involved, in other words, to achieve measurement validity (Neuman \& Wiegand, 2000). There are three steps in operationalisation, which are:

1. Choose the concept to be operationalized, e.g., necropolitics.

2. Choose a variable, or variables, to represent that concept, for example, authority, legitimacy, neutrality, and uniformity;

3. Measure the variable with responses to questions, or indicators, for example, authority can be measured by asking 'how closely are decisions that are made by the police monitored by those who govern?'

There are many options when it comes to the operationalisation of concepts and the measures of variables can be based on a range of activities, including conducting interviews and/or surveys, reading archival documents, or observing social interactions (Bachman \& Schutt, 2003).

A mixed-methods approach is used in the research, as this not only allows for the interrogation of official government statistics and reports but, more importantly, elevates the voices of Indigenous Australians who have lived-experiences of the criminal justice system. Questions asked during interviews with Indigenous Australian ex-offenders have been designed to aid in the operationalisation of the concepts of necropolitics. For example, questions such as 'How long were you in prison for?', 'What were you arrested for?', or 'Were you in a prison that your family could easily visit?' potentially uncover the concept of necropower through its variable of being subject to power.

Interviewing formerly incarcerated Indigenous Australians and analysing coroner's reports of Indigenous Australians who have died in both police and prison custody enables "stronger voices to put pressure on states to confront their actions" (Round \& Kuznetsova, 2016, p. 1018). Furthermore, this approach will elevate the voices and perspectives of Indigenous Australians in a transformative and emancipatory capacity.

The emancipatory-transformative paradigm is used for this research because it not only allows for a critical study of relations of power or oppression but also actively confronts and challenges them (Oliver, 1992). Research conducted within the emancipatory-transformative paradigm 
becomes, according to Reason "part of a developmental process including education and political action" (as cited in Oliver, 1992, p. 112). The ontological assumption here is that multiple realities are constructed by values that are socially, politically, culturally, economically, and racially informed (Chilisa \& Kawulich, 2012). Political and social action born out of political and social research has the potential not only to inform policy, but also to inform epistemology (Ali et al., 2004). As advocated by Chilisa and Kawulich (2012), an emancipatory paradigm has the highest potential to destroy myths and empower marginalised groups to change society.

The view of research as both transformative and emancipatory is also held by Dawes et al. (2017) in the context of Indigenous justice research. They posit that transformative research has huge potential for emancipatory benefits (Dawes et al., 2017). Moreover, they suggest that including the previously silenced voices of Indigenous Australian peoples in the research process provides them with a vehicle in which to express their lived experiences regarding issues that are important to them, such as the crisis of Indigenous incarceration (Dawes et al., 2017). Dawes et al. (2017) view the reflexive nature of emancipatory and transformative research as "produc[ing] slight differences to accommodate the changing nature of a research project as it progresses" (p. 20).

\section{Perceived outcomes}

By pinpointing some of the current failures in addressing pervasive issues in Indigenous incarceration, such as overrepresentation as well as enhancing an understanding of how violence across the criminal justice system can be addressed, it is perceived that the results of this project will contribute to policy changes across a wide range of areas in not only the criminal justice system, but across government agencies dealing with the issue of Indigenous incarceration, for example, child safety, housing, public health, and so on. It is perceived that the outcomes from this research will elevate the importance of incorporating Indigenous Australian worldviews and perspectives into all aspects of policy reform in the criminal justice system.

\section{Conclusion}

This paper has proposed a fresh approach to the examination of violence of Indigenous incarceration through the employment of the theoretical 
framework of necropolitics. This paper has shown how an analytical framework based on necropolitics has the potential to elevate the previously silenced voices of vulnerable populations, such as Indigenous Australians, within the criminal justice system. Additionally, it outlines the proposed research as a multi-level analysis of the overt and covert forms of violence perpetrated against Indigenous Australians within the criminal justice system and how it unlocks the potential to expose the extent to which unequal relations of power contribute to these forms of violence.

Above all, this paper has highlighted the national significance of the proposed research in identifying the necropolitical imperative in the context of the Australian criminal justice system. Additionally, it has reiterated that to gain an accurate understanding of the complexity of Indigenous incarceration, especially by non-Indigenous Australians, there must be a deeper engagement with Indigenous Australians that elevates their voices, perspectives and lived-experiences.

\section{References}

Aboriginal \& Torres Strait Islander Social Justice Commissioner. (2009). 2009 social justice report. Retrieved from https: / /www.humanrights.gov.au/our-work/aboriginal-and-torresstrait-islander-social-justice/publications/social-justice-report-0.

Agozino, B. (2010). What is criminology? A control-freak discipline! African Journal of Criminology and Justice Studies, 4(1), i - xx.

Ali, S., Campbell, K., Branley, D., \& James, R. (2004). Politics, identities and research. In C. Seale (Ed.), Researching society and culture (pp. 22-32). Sage.

Allard, T., Stewart, A., Chrzanowski, A., Ogilvie, J., Birks, D., \& Little, S. (2010). Police diversion of young offenders and Indigenous overrepresentation. Trends \& Issues in Crime and Criminal Justice, 390, $1-6$.

Alves, J. A. (2014). From necropolis to blackpolis: Necropolitical governance and black spatial praxis in São Paulo, Brazil. Antipode, 46(2), 323-339. doi:10.1111/anti.12055

Anthony, T. (2013). Indigenous people, crime and punishment. Routledge.

Anthony, T. (2009). The disavowal of context: The sentencing of lex wotton. Indigenous Law Bulletin, 7(10). Retrieved from http://www5.austlii.edu.au/au/journals/IndigLawB/2009/6.html 
Australian Bureau of Statistics. (2018b). Australian demographic Statistics. Retrieved from https://www.abs.gov.au/ausstats/abs@.nsf/mf/3101.0.

Australian Bureau of Statistics. (2018a). 4512.0 - Corrective Services, Australia, March quarter 2018. Retrieved from http:/ / www.abs.gov.au/ausstats/abs@.nsf/mf/4512.0

Australian Law Reform Commission. (2018). Pathways to justice: Inquiry into the incarceration rate of Aboriginal and Torres Strait Islander Peoples (ALRC Report 133). Retrieved from https://www.alrc.gov.au/publication/pathways-to-justice-inquiryinto-the-incarceration-rate-of-aboriginal-and-torres-strait-islanderpeoples-alrc-report-133/2-context/history-of-contact-with-thecriminal-justice-system/.

Bachman, R., \& Schutt, R. K. (2003). The practice of research in criminology and criminal justice (2nd ed.). Sage.

Baker, A., \& Cussen, T. (2015). Deaths in custody in Australia: National deaths in custody program 2011-12 and 2012-13. Retrieved from https: / / aic.gov.au/publications/mr/mr26.

Baldry, E., Carlton, B., \& Cunneen, C. (2015). Abolitionism and the paradox of penal reform in Australia: Indigenous women, colonial patriarchy, and co-option. Social Justice, 41(3), 168-189.

Baldry, E., \& Cunneen, C. (2012). Contemporary penality in the shadow of colonial patriarchy. In G. Coventry \& M. Shircore (Eds.), Proceedings of the 5th Annual Australian and New Zealand Critical Criminology Conference (1-15). Retrieved from https://papers.ssrn.com/sol3/papers.cfm?abstract_id=2196709.

Bargu, B. (2016). Another necropolitics. Theory \& Event, 19(1), 1-14.

Bassichis, M., \& Spade, D. (2014). Queer politics and anti-blackness. In J. Haritaworn, A. Kuntsman, \& S. Posocco (Eds.), Queer Necropolitics (pp. 191-210). Routledge.

Blagg, H. (2008). Crime, aboriginality and the decolonisation of justice. Hawkins Press.

Blagg, H., \& Anthony, T. (2019). Decolonising criminology: Imagining justice in a postcolonial world. Palgrave MacMillan.

Bottoms, T., \& Evans, R. (2013). Conspiracy of silence: Queensland's frontier killing-times. Allen \& Unwin. 
Brigg, M. (2007). Biopolitics meets terrapolitics: Political ontologies and governance in settler-colonial Australia. Australian Journal of Political Science, 42(3), 403-417. doi:10.1080/10361140701513554

Bromwich, R. (2017). Theorizing the official record of inmate Ashley Smith: Necropolitics, exclusion, and mulitple agencies. Manitoba Law Journal, 40(3), 191-220.

Chan, J. (2000). Globalisation, reflexivity and the practice of criminology. The Australian and New Zealand Journal of Criminology, 33(2), 118135. doi:10.1177/000486580003300202

Chilisa, B., \& Kawulich, B. B. (2012). Selecting a research approach: Paradigm, methodology and methods. In C. Wagner, B. Kawulich, \& M. Garner (Eds.), Doing social research: A global context (pp. 51-61). McGraw-Hill Higher Education.

Cunneen, C. (2011b). Punishment: Two decades of penal expansionism and its effect on Indigenous imprisonment. Australian Indigenous Law Review, 15(1), 8-17.

Cunneen, C. (2011a). Postcolonial perspectives for criminology. In M. Bosworth \& C. Hoyle (Eds.), What is criminology? (pp. 249-266). Oxford University Press.

Cunneen, C. (2007). Criminology, human rights and Indigenous peoples. In S. Parmentier \& E. G. M. Weitekamp (Eds.), Crime and human rights: Sociology of crime, law and deviance (pp. 239-261).Emerald Group Publishing.

Cunneen, C., \& Tauri, J. (2017). Indigenous Criminology. Policy Press.

Curnow, J., \& Larsen, J. J. (2007). Deaths in custody in Australia: National deaths in custody program 2007. Retrieved from Australian Insititute of Criminology: www.aic.gov.au

Curnow, J., \& Larsen, J. J. (2008). Deaths in custody in Australia: National deaths in custody program annual report 2006. Australian Institute of Criminology.

Davies, T., Isakjee, A., \& Dhesi, S. (2017). Violent inaction: The necropolitical experience of refugees in Europe. Antipode, 49(5), 1263-1284. doi:10.1111/anti. 12325

Dawes, G., Davidson, A., Walden, E., \& Isaacs, S. (2017). Keeping on country: Understanding and responding to crime and recidivism in remote Indigenous communities. Australian Psychologist, 52(4), 306315. doi:10.1111/ap. 12296. 
Drabsch, T. (2006). Reducing the risk of recidivism(15/2006). Retrieved from

https://www.parliament.nsw.gov.au/researchpapers/Pages/reducin g-the-risk-of-recidivism.aspx.

Elder, B. (2003). Blood on the Wattle: Massacres and maltreatment of Aboriginal Australians since 1788 (3rd ed.). New Holland.

Frey, R., \& Ruch, A. (2006). Biopolitics, narrative, temporality. Polygraph, $18,1-10$.

Foucault, M. (1983). Afterward: The subject and power. In H. L. Dreyfus \& P. Rabinow (Eds.), Michel Foucault: Beyond structuralism and hermeneutics (pp. 208-226). University of Chicago Press.

Gannoni, A., \& Bricknell, S. (2019). National Deaths in Custody Program: Deaths in custody in Australia 2016-17. Retrieved from https://aic.gov.au/publications/sr/sr13.

Gannoni, A., \& Bricknell, S. (2017). National deaths in custody program: Deaths in custody in Australia 2015-2016. Retrieved from https: / / aic.gov.au/publications/sr/sr12.

Hagan, S. (2017). The rise \& rise of judicial bigotry. Magpie Goose Publishing.

Haritaworn, J. (2010). The racial politics of "homophobic hate crime" in Germany. Social Justice, 37(1), 68-89.

Holcombe, S. (2016). Human rights, colonial criminality, and the death of Kwementyaye Briscoe in custody: A central Australian case study. PoLAR: Political and Legal Anthropology Review, 39(S1), 104-120. doi: $10.1111 /$ plar. 12174.

Hope, E. C., Keels, M., \& Durkee, M.I. (2016). Participation in Black Lives Matter and deferred action for childhood arrivals: Modern activism among black and latino college students. Journal of Diversity in Higher Education, 9(3), 203-215. doi.org/10.1037/dhe0000032.

Howlett, C. (2009). Cultures of institutional violence: Deaths in juvenile detention. Journal of Australian Studies, 19(43), 24-35. doi: $10.1080 / 14443059509387196$.

Klippmark, P. (2016). Justice for Ms Dhu: Disrupting the framing of state violence and Indigenous women's deaths in custody through commemoration in the public sphere. [Bachelor of Laws Honours, Griffith University, Australia]. 
Klippmark, P., \& Crawley, K. (2017). Justice for Ms Dhu: Accounting for Indigenous deaths in custody in Australia. Social \& Legal Studies, 27(6), 695-715. doi:10.1177/0964663917734415

Kwate, N. O. A., \& Threadcraft, S. (2018). Dying fast and dying slow in black space. Du Bois Review: Social Science Research on Race, 14(02), 535-556. doi:10.1017/s1742058x17000169

Lumsden, K., \& Winter, A. (2014). Reflexivity in criminology. In K. Lumsden \& A. Winter (Eds.), Reflexivity in criminological research: Experiences with the powerful and the powerless (pp. 1-19). Palgrave Macmillan.

Lyneham, M., \& Chan, A. (2013). Deaths in custody in Australia to 30 June 2011: Twenty years of monitoring by the National Deaths in Custody Program since the Royal Commission into Aboriginal Deaths in Custody. Retrieved from https: / / aic.gov.au/publications/mr/mr20.

Lyneham, M., Larsen, J. J., \& Beacroft, L. (2008). Deaths in custody in Australia: National Deaths in Custody Program 2008. Retrieved from https://aic.gov.au/publications/rpp/rpp85.

Lytle, C. (2017). Violence, borderlands and belonging: The matter of black lives and others. Coolabah, 21, 71-68. doi:10.1344/co20172171-86

Mbembe, A. (2003). Necropolitics. Public Culture, 15(1), 11-40.

McCabe, J. L., \& Holmes, D. (2009). Reflexivity, critical qualitative research and emancipation: A Foucauldian perspective. Journal of Advanced Nursing, 65(7), 1518-1526. doi:10.1111/j.1365-2648.2009.04978.x.

Moreton-Robinson, A. (2015). The white possessive: Property, power, and Indigenous sovereignty. University of Minnesota Press

Morseu-Diop, N. (2017). Healing in justice: Giving a voice to the silent and forgotten people. Magpie Goose Publishing.

Neuman, W. L., \& Wiegand, B. (2000). Criminal justice research methods: Qualitative \& quantitative approaches. Allyn \& Bacon.

O'Leary, Z. (2004). The essential guide to doing research. Sage.

Oliver, M. (1992). Changing the social relations of research production? Disability, Handicap \& Society, $7(2), \quad 101-114$. doi:10.1080/02674649266780141

Parsons, K. A. (2007). Structural violence and power. Peace Review, 19(2), 173-181. doi:10.1080/10402650701353612 
Petray, T. (2012). A walk in the park: Political emotions and ethnographic vacillation in activist research. Qualitative Research, 12(5), 554-564. doi: $10.1177 / 1468794112446048$

Rana, J., \& Rosas, G. (2006). Managing crisis: Post-9/11 policing and empire. Cultural Dynamics, 18(3), 219-234. doi:10.1177/0921374006071613

Razack, S. H. (2013). Timely deaths: Medicalizing the deaths of Aboriginal people in police custody. Law, Culture and the Humanities, 9(2), 352374. doi:10.1177/1743872111407022

Razack, S. H. (2012). Memorising colonial power: The death of Frank Paul. Law and Social Inquiry, 47(4), 908-932.

Reynolds, H. (2013). Forgotten war. NewSout Publishing.

Reynolds, H. (2012). A history of Tasmania. Cambridge University Press.

Reynolds, H. (2006). The other side of the frontier: Aboriginal resistance to the European invasion of Australia. University of New South Wales.

Reynolds, H. (2001). An indelible stain? The question of genocide in Australia's history. Penguin.

Round, J., \& Kuznetsova, I. (2016). Necropolitics and the migrant as a political subject of disgust: The precarious everyday of Russia's labour migrants. Critical Sociology, 42(7-8), 1017-1034. doi:10.1177/0896920516645934

Rowe, S. (2014). A spirit that can't be broken: Re-storying an Indigenous woman's experience of criminalisation through a critical Indigenous research praxis'. [Unpublished Honours Thesis, Bachelor of Social Work, James Cook University, Australia].

Rowe, W. (2014). Positionality. In D. Coghlan \& M. Brydon-Miller (Eds.), The SAGE encyclopedia of action research. Sage. doi: $10.4135 / 9781446294406$

Scheper-Hughes, N. (2006). Death squads and democracy in northeast Brazil. In J. Comaroff \& J. Comaroff, L (Eds.), Law and order in the postcolony (pp. 150-187). University of Chicago Press.

Sclofsky, S. (2016). Policing race in two cities: From necropolitical governance to imagined communities. Journal of Social Science (Online), 6, 1-24.

Sithole, T. (2014). Achille Mbembe: Subject, subjection, and subjectivity. [Doctoral thesis, Literature and Philosophy, University of South Africa].

Retrieved

from 
http://uir.unisa.ac.za/bitstream/handle/10500/14323/thesis_sith ole_t.pdf?sequence $=1$

Smith, C. A. (2016). Facing the dragon: Black mothering, sequelae, and gendered necropolitics in the Americas. Transforming Anthropology, 24(1), 31-48. doi:10.1111/traa. 12055

Smith, C. A. (2015). Blackness, citizenship, and the transnational vertigo of violence in the Americas. American Anthropologist, 117(2), 384-387. doi:10.1111/aman. 12242

Soyinka-Airewele, P. (2015). The end of politics? Reclaiming humanity in an age of biopower and necropolitics. Public Lecture Series, 4(2), 148.

Tedmanson, D. (2008). Isle of exception: Sovereign power and Palm Island. Critical Perspectives on International Business, 4(2/3), 142-165. doi: 10.1108/17422040810870042.

Ticehurst, A., Napier, S., \& Bricknell, S. (2018). National Deaths in Custody Program: Deaths in custody in Australia 2013-14 and 2014-15. Retrieved from https://aic.gov.au/publications/sr/sr5.

Vadasaria, S. (2015). Necronationalism: Managing race, death and the nation's skeletons. Social Identities, 21(2), 117-131. doi: 10.1080/13504630.2015.1041014

Wahlquist, C. (2016). Aboriginal deaths in custody: 25 years on, the vicious cycle remains. Retrieved from https://www.theguardian.com/australianews/2016/apr/15/aboriginal-deaths-in-custody-25-years-on-thevicious-cycle-remains.

Wolfe, P. (1999). Settler colonialism and the transformation of anthropology: The politics and poetics of an ethnographic event. Cassell.

\footnotetext{
1 Western Australia, Victoria and Tasmania do not record the Indigenous status of offenders.
} 